\title{
Application of Environmental Friendly Architecture on Cottage in Pulau Lancang Kecil, Kepulauan Seribu
}

\author{
Rahadian Mahdi ${ }^{1}$, Tri Endangsih ${ }^{2}$ \\ \{rahadianmahdean@ gmail.com ${ }^{1}$, tri.endangsih@budiluhur.ac.id ${ }^{2}$ \}
}

Faculty of Engineering, Program of Architecture, Universitas Budi Luhur, Jakarta, Indonesia ${ }^{1,2}$

\begin{abstract}
To meet refreshing needs, the residents of Jabodetabek area can take advantage of tourism areas nearby Jakarta that do not take a lot of time to travel. One of which is recreation to Kepulauan Seribu that has the beauty of nature. Kepulauan Seribu is a tourist destination that can be a solution for the matter above since its location is still in the area of Jakarta. The development of water tourism area in Pulau Lancang Kecil is a starting step to improve an existing one tourism facilities in Pulau Lancang Kecil. Pulau Lancang Kecil as a favourite tourist area in Kepulauan Seribu is now a tourist destination of Jakarta residents. Due to the increasing of tourists to Pulau Lancang Kecil, it is necessary to develop the suitable area around Pulau Lancang Kecil in accordance with its potential. The development of water tourism area in Pulau Lancang Kecil is a solution in order to rearrange Pulau Lancang Kecil that has a natural beauty the sea. One aspect of its development is planning the construction of cottage as one of the supporting facilities of tourism. By the availability of cottages in Pulau Lancang Kecil, it is expected to meet the needs of tourism resort for Jakarta people and increase revenue for the government of Jakarta. Eco-friendly architecture will be applied to this cottage because Kepulauan Seribu has good natural potential and can support the functions and activities in the building.
\end{abstract}

Keywords: Eco-Friendly Architecture, Cottage in Pulau Lancang Kecil, Kepulauan Seribu.

\section{Introduction}

In general, Jakarta is known as a city of government filled with high buildings and full of activity, whereas Jakarta is inseparable from Kepulauan Seribu which is the area of Jakarta waters. Kepulauan Seribu has 110 islands, covering from the bay area of Jakarta to Sebira Island with an area of $6,997.5 \mathrm{~km}^{2}$ of sea and a land area of $8.6459 \mathrm{~km}^{2}$ [1]. Kepulauan Seribu is a very attractive tourist destination and very near the urban areas. Tourism activities such as marine tourism can be one of the most important aspects in development of the Indonesian state, which is an archipelago country that is very rich in maritime potential, especially capital city of DKI Jakarta which has the potential of marine tourism that is Kepulauan Seribu. The Government of DKI Jakarta has responsibility for the development in Kepulauan Seribu. 
Nowadays tourism has turned to be the needs of people in various groups, especially for the city of DKI Jakarta filled with a variety of activities. So they need spare time to break for a while from these activities and enjoy the beauty of nature by having vacation. Therefore, it required serious handling to achieve all the destinations in the field of tourism. One of the ways is by developing tourism areas, so that the potential and attractiveness of tourism resort can be more productive and able to attract potential tourists to visit and enjoy the sights. Kepulauan Seribu, which is part of DKI Jakarta area, has the potential to be developed as a marine tourism destination for domestic or foreign citizens. This can make the Kepulauan Seribu as a tourism place as tourism resort in Bali. To make it happen, it takes a great effort and requires a planned system to achieve a good result.

Kepulauan Seribu located in the Java Sea and Jakarta Bay is an area with characteristics and natural potential that is different from other DKI Jakarta areas because this region is basically a cluster of coral islands formed with coral biota and its bunch (algae, malusho, foraminifera, etc.). It is natural dynamics process. In accordance with these characteristics and development policies of DKI Jakarta, Pulau Lancang Kecil is an island geographically located in the northern part of Java Island which is geographically included in Pulau Pari territory, district of South Kepulauan Seribu, Kepulauan Seribu Regency [2]. It has white-sand beaches and aqueous greenish sculpture.

To encourage the successful development of tourism in Pulau Lancang kecil, various facilities and infrastructure is required to prepare. Those can also support the function of the area and can provide employment for local residents. In addition, it can increase government revenue in tourism field. This inspires to create a tourist area with temporary lodging or cottages. By various supporting facilities and the ideal concept with the function and condition of the area that has not been processed, it can be a productive area in the field of tourism [3].

The development of maritime tourism into an international tour requires a total effort, such as taking into account the sea transport system such as ships that must also be international standard with safety devices that meet the standards, so that local or foreign tourists do not hesitate to travel because of the guarantee of safety and comfort. Therefore, the design of ships as a means of sea transportation should be prepared. In this case, the ship is not only as a transportation system, but also become one of the tourist attractions to feel the sensation or an interesting experience with a comfortable and safe boat ride. It can be realized if the ship has a good standard and class. In addition to the transportation system, other things to note are the tourist objects that are also a major component in the development of integrated marine tourism.

The purpose of writing the Development of Water Tourism Area in Pulau Lancang Kecil is as a step action plan to develop a general tourist area of Pulau Lancang Kecil. The purpose of the activities of water development and water tourism area in the small island of Pulau Lancang Kecil as favourite tourism area in Kepulauan Seribu is to provide a water resource development planning document in the eastern region of Pulau Lancang Kecil. Thus, it can make Kepulauan Seribu as a sustainable marine tourism.

\section{Research Method}

In relation to the above research problems, the researcher uses a quantitative and qualitative approach, where the collected form of opinions, responses, information, concepts and explanations in the form of a description in expressing the problem. Quasi-tatif research is 
a series of activities or process of filtering data or information that is reasonable about a problem in certain conditions, aspects or fields in the life of the object [4].

Quantitative method is a method that describes the existing situation in the field by involving all stakeholders in the management of marine tourism in the thousand islands, especially the island of Lancang Kecil. The data collected includes primary and secondary data. The application of quantitative methods to analyze the needs and magnitude of space in each building period. Qualitative method is an approach in conducting research oriantation on the symptoms of a natural nature because of its orientation so, it is naturalistic and fundamental or nature original and can not be done in the laboratory but must plunge in the field. Therefore, this kind of research is called field study [5]. Field study is a method of learning through the collection of data directly by observation, interview, record, or ask questions. the process of learning takes place directly in the field. understanding of qualitative approaches in research with field study method is the research stage that produces descriptive data in the form of written or oral words about humans, observable behavior so as to find the truth that can be accepted by human reason. The following qualitative approach applied in this research are as follows:

\subsection{Spatial Approach}

Spatial approach is intended that in developing water tourism area on the Pulau Lancang Kecil is done by observing the study area with all the potential and constraints contained there, so that the development of water tourism area on Pulau Lancang Kecil is achieved. However, this development remains paying attention and utilizes the existing potential. Spatial approach is used to observe the supply side of the tourist market that is considering Pulau Lancang Kecil as tourism area consisting of several sub-areas that have different potential. Thus, the intention of developing agro tourism needs to be done to select the most appropriate location, so the application of development efforts can be done optimally and supported by other tourist sub-region contained in the tourist area of Pulau Lancang Kecil as a form of new tourist offer to the tourists.

\subsection{Result Approach}

Natural resources and environment determine the type, quantity, and quality of water tourist development in Pulau Lancang Kecil. This approach emphasizes supply factors rather than demand factors. Natural factors, ecological considerations, environmental carrying capacity, and so on are more dominant in terms of social factors and the demands of human needs.

\subsection{Activity Approach}

This approach is based on common tastes and desires by first reviewing past activities to estimate the opportunities that need to be contained in the future. The emphasis of this approach is on the "user". In the process of planning, it is heavily influenced value of certain groups that is a well-organized group of values. This approach can work best if applied to homogeneous populations with limited scope.

If this approach is done in large cities with heterogeneous populations, it will be difficult to determine the types of activities that are mutually agreed upon because the heterogeneous population has diverse lifestyles, values, and socioeconomic levels.

\subsection{Human Behavior Approach}


This approach is based on an assessment of the attitudes and behaviours of residents in using leisure time (how, when, and where). The emphasize is on tourism activities as an experience, which is why people conduct travel activities, what kind of the most favourable tourist attractions, and what are the benefits derived from the trip. The desires, preferences, and satisfaction of the user of a tourism object determine the planning process.

This approach is used to understand market segmentation based on the characteristic of tourists so that the researchers can find out the market tendency from the opinion of tourists about the motivation, perception, and expectations that tourists want to develop the study area.

The results of this approach are used to further analyse in order to get the most appropriate form of development to be applied in Pulau Lancang Kecil.

\subsection{Demand and Supply Approach}

This approach combines elements of demand, supply, and identifies the social needs indicator to prepare the physical environment (space) that is compatible with human behaviours. This approach covers a wider range of possibilities than traditional recreational parks in general.

\subsection{Development Approach}

The exploring of tourism potential of Pulau Lancang Kecil has not been optimal yet. It caused the tourism activity in the area is less diverse and less well-coordinated. This development approach is used to direct the research that will be carried out to formulate the concept of agro-tourism development that is suitable to be applied in Pulau Lancang Kecil area to increase the development of the tourist area as a whole, both for Pulau Lancang Kecil itself and for the development of tourism in Kepulauan Seribu.

\section{Results And Discussion}

\subsection{Definition of Tourism and Tourists}

Tourism is a term given when a tourist travels or in other words the activities undertaken when a visitor travels [6]. Shortly, tourism can be formulated as an activity in a tourist-related society [7]. The definition of tourists by Norval (Yoeti, 1995) is anyone who comes from one country to another whose reason is not to stay or work on a regular basis, but to temporarily spend the money [8].

\subsection{Development of Water Tourism}

Tourism development is an effort to promote tourism activities to create tourism conditions that can generate foreign exchange. The development of tourism, especially the development of water tourism, is not only fixing the natural attractions and waters or only doing the development of accommodation and restaurants, but far more extensive than that. Tourists who come still need facilities, transportation, water attractions, service, souvenirs, safe atmosphere, and others. 
The development of water tourism is influenced by several factors such as the number of visitors, the availability of transportation, supporting facilities (such as hotels, restaurants, and entertainment facilities), and the promotion and existing water attractions. Within the framework of developing water tourism, there are other forming component included in the tourism system, such as tourists, tourist attractions, service facilities, transportation, information, and promotions.

Tourist attractions and facilities are the main basis of tourism. If it is not fulfilled then the tourists will not have the motivation or desire to visit these attractions [9]. Robinson pointed out that there are six main elements for the formation of tourist attraction in tourism development, including water tourism, that is:

1. Weather, is a special feature of tourism that causes a location to be potential for tourism.

2. Landscape, attraction in the form of interesting view.

3. Facilities, consisting of two types of nature and artificial.

4. History and culture, historical relics or cultural arts of a region.

5. Accessibility, the easier to reach the tourist location the higher the possibility to visit.

6. Accommodation, regarding lodging and places to eat. An important factor in the formation of tourist attraction can also be used as a reference for the development of water tourism as has been stated by Robinson before, but added with the hospitality of surrounding residents who can create a fun atmosphere for tourists who visit the area of water tourism.

\subsection{Water Tour Facilities}

To support the development of water attractions, it is necessary to consider the necessary tourist attraction facilities. These facilities include the provision of recreation, cultural and social activities, entertainment and sports, shopping, administrative sections, technical services and other additions described as follows [10]:

1. Recreation, sports, and cultural and social activities.

Collective facilities should be carefully arranged and set to increase the excitement of the tourists, to generate attraction and invite participation, and to attract a large audience, and the most important is to make tourist comfortable.

2. Stores, shop stalls, and related services.

Trading facilities in holiday destinations are somewhat different from those in towns or villages of the same size, not only in the type of store type, but also in numbers, since tourists expect to find many shops in the tourist area, especially if they do not carry private car or in a tourist attraction that has difficult access.

3. Administrative, technical and other supporting services.

The extent or the number of services that are accommodated in the tourist area depends on the location or location, the number of non-tourist residents, the proximity of other large cities, and the extent or extent of regional public service administration.

Water tourism facilities that are physical and must be considered its availability around the tourist area to support the existing attractions, among others, are as follow:

1. Dock, where a boat takes place and also serves as a road connecting the mainland with a boat;

2. Marina, which is a public facility on the edge of the water to lie at anchor and boat ship base for tourist purposes

3. The tourist information centre, which is the information facility for tourists who provide information and tourist guides; 
4. Shelter, which is the viewing station facilities that are scattered in strategic places on the edge of the water;

5. Accommodation, for example lodging facilities such as hotels, motels, cottages, camp, or guest house;

6. Support facilities, including praying area, lavatory (bathroom), and souvenir shop;

7. Playground, which is an area in tourist area that is used as a playground for children;

8. Water sports facilities; this facility utilizes the potential of existing waters as a place to have sport which is also an attraction for tourists as a show or scenery among other attractions;

9. Open space, is a tourist orientation to go to another object that also serves as a sitting ground to enjoy the scenery.

\subsection{Tour Activities in Kepulauan Seribu}

Previously, the goal of Kepulauan Seribu tourism development is marine tourism, which begins with the granting of permits for 43 companies to manage the island to build resorts and manage marine tourism activities. Now only 9 islands are served as a resort with marine tourism activities that can be categorized as leisure and pleasure. This tourism activity is less successful in accommodating the demands of the community to be involved, because of the gap between the demands and the quality of tourism human resources.

Meanwhile, there are visits of the general public, whether adults or adolescents, to the settlement islands to travel. Therefore, the community provide homestays. With the establishment of Kepulauan Seribu district administration, the government facilitates the form of tourism whose management involves the locals, as shown in the development of tourism activities in Pulau Lancang Kecil. Tourist resort markets are different from Pulau Lancang Kecil Island, in socioeconomic class and in organizing activities. Similarly, there is a difference between visitors of Pulau Lancang Kecil and the settlement islands.

\subsection{Program Development for Kampung Lancang Kecil}

The area of water tourism in Kepulauan Seribu cannot be separated from the development of the entire archipelago in Kepulauan Seribu. The development stage in the general tourist area of Pulau Lancang Kecil will be described below. The concept of developing Pulau Lancang Kecil is eco-friendly architecture concept which is environmental arrangement by utilizing the potential or natural resources and the use of technology based on environmentally friendly ethical management [11],[12]. The patterna of planning and design of eco architecture are as follows [13],[14]:

1. Buildings can accommodate and function properly by observing the peculiarities of human activity and the potential use of the surrounding environment in shaping the image of the building.

2. Utilizing the latest natural resources located around the planning area for building systems, whether related to building materials or for building utilities (energy sources, water supply).

3. Healthy building, which means that does not give negative impact to human health in process, operation / after-hours, and when demolition. It also includes a healthy location, healthy ingredients, healthy shape, and a healthy atmosphere.

4. Architectural elements are as optimal as possible to provide protection against heat, wind and rain. 
5. The energy intensity contained in the materials used during construction should be as minimal as possible, in the following ways:

- Substitution, minimization and optimization of non-renewable energy sources.

- The establishment of an intact cycle between the supply and disposal of building materials, energy, or waste is avoided as far as possible.

- $\quad$ The use of humane appropriate technology.

\subsection{Results Planning}

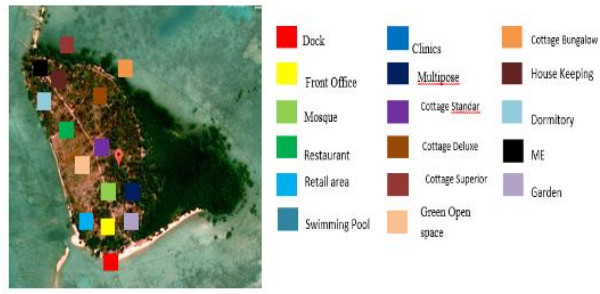

Fig. 1. Concept of Site Planning. (Source: Field Data (processed), 2016)

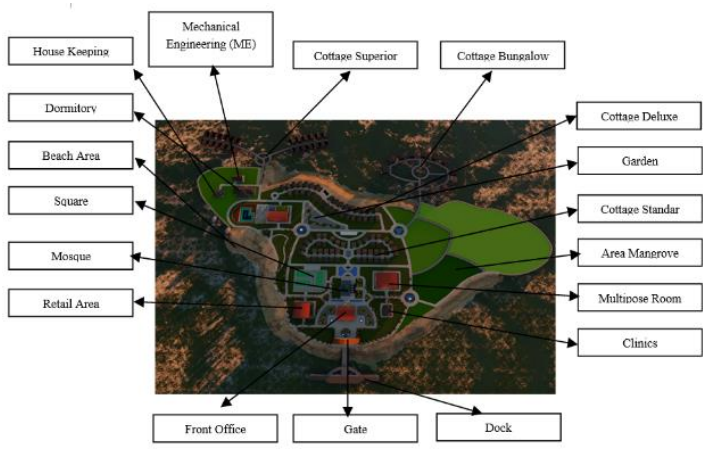

Fig. 2. Concept of Building Mass Management. (Source: Field Data (processed), 2016)

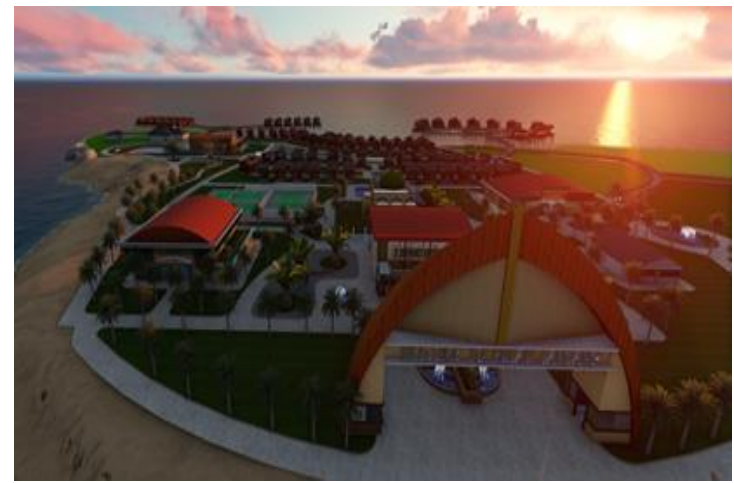

Fig. 3. 3D building mass allocation. (Source: Field Data (processed), 2016) 

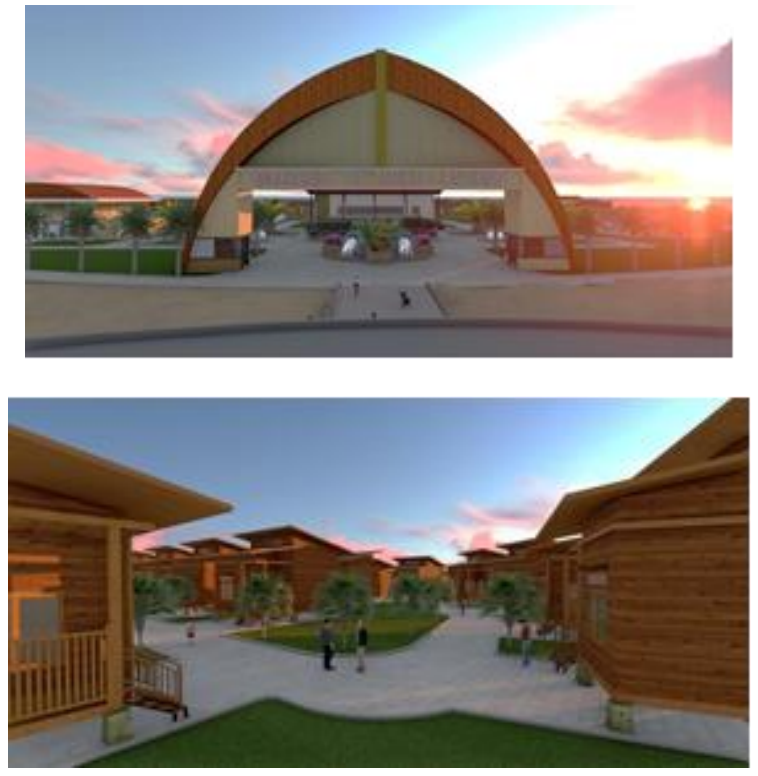

Fig. 4. Cottage Setup. (Source: Field Data (processed), 2016)

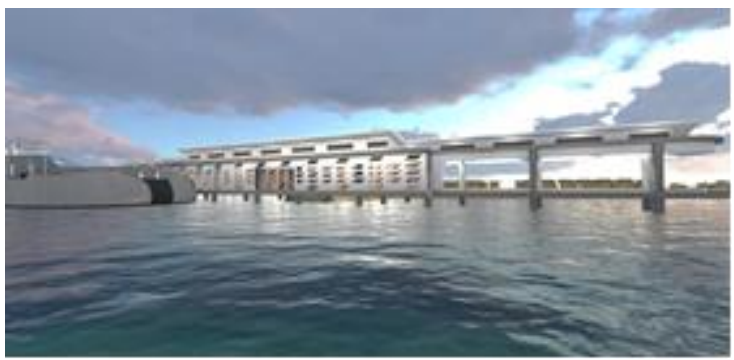

Fig. 5. Dock Development. (Source: Field Data (processed), 2016)

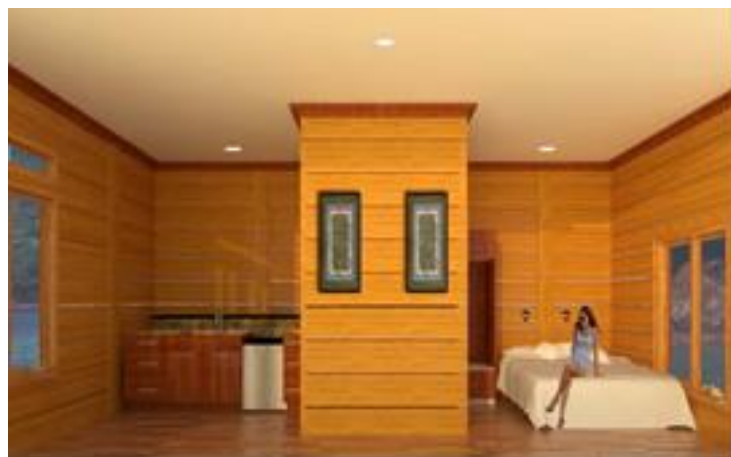




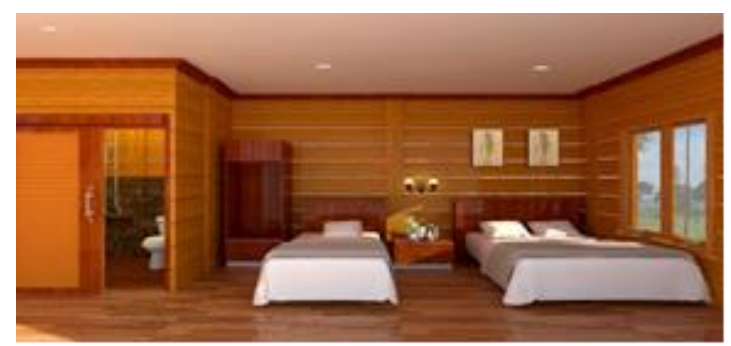

Fig. 6. Concept of Type Cottage Setup. (Source: Field Data (processed), 2016)

\section{Conclusions}

The development of Pulau Lancang Kecil as a water tourism area in Kepulauan Seribu, can be summarized as follows:

1. Pulau Lancang Kecil has two clusters of islands: Pulau Lancang Kecil Besar dan Pulau Lancang Kecil Kecil, where Pulau Lancang Kecil Besar as a settlement that has developed into water tourism. Meanwhile, Pulau Lancang Kecil Kecil is as nature conservation area.

2. The development of Pulau Lancang Kecil as a water tourism area in Kepulauan Seribu is focused on the development of existing condition by improving facilities such as infrastructure.

3. Development of Pulau Lancang Kecil in the eastern zone is planned as a water tourism area;

4. The concept of developing Small Lancang Island with the concept of 'Environmentally Friendly' means the arrangement of the environment by exploiting the potential or natural resources and the use of technology based on ethical management environmentally friendly, so it is expected that in addition to the new magnet will also occur even distribution of development in all environmentally friendly tourism sector for tourism sustainability.

Acknowledgements. Thank you to the people of Pulau Lancang Kecil who have allowed researchers to observe and collect the data, and for inputs to prepare the planning concepts and all those who have provided data supporting this research.

\section{References}

[1]Bappeda DKI Jakarta, “Portal Bappeda DKI Jakarta,” 2017. .

[2]Wordpress, "Pulau lancang Kecil," 2015.

[3]Putu Shintani Utari dan I Made Adi Kampana, "Perencanaan Fasilitas Pariwisata (Tourism Amenities) Pantai Pandawa Desa Kutuh Kuta Selatan Badung,” J. Destin. Pariwisata, vol. Vol. 2 No., 2014.

[4]Hadari Nawawi, Penelitian terapan. Yogyakarta: GAMA Press, 1994.

[5]M. Nazir, Metode Penelitian. Jakarta: Ghalia Indonesia, 1988. 
[6]Annisa Muawanah, "Definisi, Komponen, Dan Sistem Pariwisata," 2013. .

[7]R. G. Soekadijo, Anatomi pariwisata, Cetakan 2. Jakarta: Gramedia Pustaka Utama, 2000.

[8]O. A. Yoeti, Pengantar Ilmu Pariwisata. Bandung: Angkasa, 1995.

[9]Harry Robinson, A geography of tourism. Macdonald and Evans, 1976.

[10]Loveyrain, "Sarana dan Prasarana pendukung wisata," 2016. .

[11]M. Style, “Green Architecture," http://adacyntya.blogspot.co.id/2015/04/arsitektur-ramahlingkungan.html, Apr-2015.

[12]F. S. and Z. M. A. Y. Gorji Mahlabani, "Eco-Village, Amodel Of Sustainable Architecture," J. Fundam. Appl. Sci., vol. Vol.8 No 3, 2016.

[13]Fitri Rahmafitria, "Eco-Resort And Green Hotel In Indonesia An Application Of Sustainable Tourism Development," J. Manaj. Resort Leis., vol. Vol 11. No, pp. 1-22, 2014.

[14]L. P. Fifi Ambarwati, Agung Kumoro W., "Hotel Resort Dengan Pendekatan Arsitektur Ekologis Di Batu Malang,” Arsitektura, vol. Vol. 15 No, 2017. 